\title{
The Latin American Exile Experience from a Gender Perspective: A Psychodynamic Assessment
}

\author{
Marlinda Freire
}

\section{Introduction}

Organized violence against individuals leads to a breaking point in their lives. Among other traumas, it results from exposure to death fears, an inability to use culturally acquired coping and grief reactions, a loss of meaning (loss of individuality in the face of annihilation), numbed and constricted personalities, fixation on an unfinished past, and severed bonds with common heritage (Dasberg 1986).

In the last two decades, Latin Americans have experienced organized violence brought about by dictatorship and civil war. As a result, a large segment of the Latin American population has been forced into exile. Life outside the homeland is typically preceded by life-threatening experiences involving the individual, the immediate family, the group of reference, and society at large. The individual goes into exile with a core sense of culture and linguistic identity, as well as a background of personal experiences. These will be retained through a series of extreme traumatic experiences and through asylum-seeking and resettlement, with all the massive and nonanticipated violent losses this entails. The abrupt uprooting is often followed by an alienating encounter with an unknown culture and new language (Freire 1989; 1993).

In exile, the individual faces tasks which offer possibilities of continuity versus discontinuity, similarities versus differences, acceptance versus rejection, resistance versus adaptability, and integration versus lack of integration. Given the abrupt, violent, and forced nature of refugee experiences and the short period of time in which

Dr. Marlinda Freire is the Chief Psychiatrist for the Toronto Board of Education in Toronto, Ontario. these experiences are encountered, the individual needs to make drastic intrapsychic accommodations. As a mechanism for coping and survival, the individual initially attempts to transfer, duplicate, or rescue any aspect of the old life and the old self that may permit a continuity of self-identity, thereby reinforcing his/her cultural and linguistic core self (Freire 1990a, $1990 \mathrm{~b}, 1991)$. In order to move toward a new self, incorporating elements of the new language and culture, the individual needs to find new and meaningful life commitments in an environment that is perceived as being receptive and appreciative of what s/ he has to offer, while also providing new opportunities for the newcomer. An individual will constantly compare the old self (who s/he was, what s/he had, what $s$ /he knew) with the new self (who s/he is, what s/he has, what $\mathrm{s} /$ he knows). For a healthy integration with the least possible conflict, the individual needs to be left with a positive balance when making this comparison (Freire 1993a; 1993b).

The sum of the refugee experiences acts to disassemble the individual's intra-psychic structure, leading to a state of psycho-emotional disorganization that tests the sense of identity to its utmost. Ideally, individuals will, with time, find some partial resolution for their experiences at personal and collective levels. Those who manage particularly well achieve the restructuring of a core sense of identity, with some degree of healthy resolution, through a balanced, bicultural, and bilingual "new self" constructed from the remains of a traumatized monocultural/monolingual self (Freire 1989; 1991; 1993; 1993a; 1993b).

From a psychodynamic perspective and based on longitudinal developmental observation of the Latin American refugee community in Toronto, as well as clinical and research work performed in this community during the last two decades, I have identified gender-differentiated patterns of responses and outcomes of Latin Americans living in exile.

Though this work is based specifically on experience with the Latin American refugee population in Toronto, consultation with colleagues working with Latin Americans exiled in other cities in Canada and in other parts of the world suggests that these findings and observations are not unique to Toronto, nor to Canada (Carli 1991). Psychiatric services that I offered to refugees of other ethnic groups in Toronto also seem to indicate a similarity of findings and insights when comparing the experiences of women and men. However, this is a qualitative study that needs to be validated in a hypothesis-testing investigation.

The thesis of this study is that, from a psychodynamic perspective, given comparable time in a new country and similar post-resettlement experiences, gender seems to protect women better than men. Latin American refugee women, in general, tend to respond better than their male counterparts to the prolonged identity crisis and other crises inherent in the process of exile, from the following perspectives: a) continuity of meaningful vital tasks; $b$ ) securing new meaningful vital tasks; c) coping mechanisms and adjustment strategies; and d) restructuring of a new bicultural/bilingual self, thereby facilitating adaptation to and integration in the new country.

\section{Latin American Refugee Women and Exile}

Latin American women have filled the traditional role assigned to women in many societies-they have been largely confined to the microsystems 
of the family and immersed in the endless tasks of childrearing, housekeeping, and caring for their husbands. Women working outside the home are in low-status, low-paying jobs. Women with higher levels of education are almost always in positions subordinate to men. Work only adds an additional, secondary role to their core identity as mothers and wives. The indigenous societies of Latin America were traditionally patriarchal. Introduction of Roman Catholicism by the Europeans only served to reinforce and legitimize women's positions of subservience, humility, sacrifice, and asexuality by giving this position religious meaning (Valenzuela 1987). Though differences in social class, level of education, and other subcultural aspects are reflected in the lives of Latin Americans, most women, even today, share a core sense of self based on motherhood and their roles as wives. Latin American women, even the most progressive and liberated among them, have as a vital agenda to secure the well-being of their children and husbands, and to preserve the family unit.

In experiencing the repressive regimes that trigger every step of the refugee process and those of exile, Latin American women respond with a set of coping, survival, and adaptive mechanisms. These have been imprinted upon them by the processes of cultural socialization and religious indoctrination, and have geared them toward providing for and protecting their loved ones, and ensuring that they remain together. When they are not themselves tortured, missing, or killed, women generally risk their own lives to search for their loved ones, to get them out of concentration camps and to seek asylum for them, or to focus international attention on their plight. Women usually survive on their own emotionally and financially (as their support system frequently collapses) throughout the ordeal preceding resettlement. In cases where men go into exile first, it is not unusual for women to provide their male partners with some financial assistance during the transition period in the new country. Once the men have fled, women work tirelessly to reunite their families, while simultaneously attempting to maintain some sense of family stability in highly anomalous circumstances.

In identifying their sources of strength, women invariably focus on their moral obligation towards their family. Sixty percent of those women in my care have left their countries to keep their families intact and to prevent their children from losing their fathers (Freire 1992).

Testimony: "I was able to do whatever needed to be done because my husband's and children's lives were at stake. I have always felt that if they hadn't been there, I wouldn't have had any reason to continue on living and fighting".

Once reunited with their husbands in the country of asylum, women appear to readily find meaningful tasks again, exercising coping and adaptive mechanisms that are more effective than the ones exercised by their male partners. Women are usually the ones who secure the basic survival of the family. While the domestic tasks are traditionally assigned to them, it is also fairly common for women to initially accept any menial work to provide the family with immediate income, a role which may be new to them. The responsibilities, both old and new, with which women are faced are thus quite significant. This is compounded by the fact that, most frequently, women do not qualify for government-sponsored English as a Second Language (ESL) or other job-oriented training. Since they are not considered by Canadian policies as "head of family," and as they frequently have lower levels of education than their partners, women support their partners as the men learn the new language, try to recover their working qualifications, and continue their political work to improve conditions in the native country. Moreover, women allow their partners the personal space they need to start recovering the old self and restructuring or "reinventing" the new self while women themselves, in general, do without that kind of support.

Under normal circumstances, and within the socioeconomic status to which they belong in their home country, Latin American women are accustomed to having fewer opportunities than men, to assuming that they must be able to cope with whatever situation arises, to drawing something positive out of the most taxing experiences, and to being thankful for whatever assistance, if any, they receive from others. This is the basis for the coping mechanisms of women, their tremendous resources for survival, and their heightened resilience in facing crises as compared with their male counterparts. Women's reproductive functions, with all the organic losses (menstruation, pregnancies, breastfeeding) they entail, may also give women additional biological resilience. The psycho-emotional survival and adapting mechanisms to situations of oppression and abuse, inherent in women's positions in society, give them additional psycho-emotional resources and strengths (Freire 1992). Some of the documented characteristics include their capacity to continue their daily activities under the most adverse life circumstances and when affected by serious emotional and physical symptoms (Brown and Harris 1978, 283).

Testimony: "I was so sad and afraid when we just came. I felt I couldn't stop crying but I soon realized no one was going to do my job. I realized that if I couldn't pull myself together for my own sake, I had to do it for my children and my husband. The children had to go to school and somebody had to do the cleaning and cooking. My husband spent most of his time going to English classes and he joined other comrades working for Chile. A lady asked me to take care of her two little children and I didn't understand that she was going to pay me until she gave me some money. At the beginning I didn't understand the mother or the children, but slowly we were able to communicate a little. I don't really remember when I started to be less sad and scared." 
The important point is that in facing exile and initial resettlement, women do not need to find new meaningful tasks or ones that offer continuity to their sense of existence. They have a task that was not lost throughout the ordeal preceding resettling: the care of their husbands and children. Even in cases where women are separated temporarily from their husbands or children, there is always someone for whom women are providing, which leaves them protected and untouched in their maternal role. There are indications that when refugee women, for whatever reason, are unable to fulfil their maternal role, they become depressed and "go crazy" (Reynell 1989, 157-58). Women usually feel that adapting to the demands of the new society does not involve much risk in terms of personal threats (in areas of self-development) or pressures to perform. They usually feel they have little to prove to themselves or others. Their primary domain was and continues to be, at least initially, the domestic one, and with a strengthening of their basic coping and survival mechanisms, they manage to accomplish all the basic tasks that secure the continuity and survival of the family. Women also seem to reach the stage of psychological arrival (Tyhurst 1951)-the recognition and acceptance that exile is going to be a prolonged situationsooner than men. This may again be the result of women's experiences of having to face the realities of everyday life, which translates at a functional level into starting to build a new "nest" for the family under whatever circumstances are present.

The women, in general, are the ones who keep an open communication with their children, and who keep the native language alive at home, since they usually spend more time with their children and talk more with them. It is also typical for women to become mediators between children and fathers in their negotiation of the two cultures. And women adopt the role of cultural mediators as a way of preserving the family and protecting their children against what they per- ceive as the alienation of the new culture. Women do all of this intuitively as a reaction to perceived threats to ethnic and cultural identity. These defences also contribute to inter- and intra-generational family integrity and continuity.

Thus, women shift from the more restricted experiences of home and family to a broader range of new experiences including the wage economy, the learning of a second language, the search for a new support system, and the attempt to find some balance between the old and the new life for the sake of their families. Success in accomplishing all the initial tasks that secure a basic functioning of the family, though variable, soothes women's massive losses, changes, and disruptions and gives them some sense of competence and control over the new environment. Their performance in the new situation reinforces their self-esteem while bolstering their core identity as mothers and wives. A study of 36 Latin American women subjected to torture in their homelands indicated that all the women were working, studying, and/or performing housework one year after their initial evaluation (Fornazzari and Freire 1990). Unfortunately, it is not possible to compare these figures against those of their male counterparts as no similar study with men has been carried out. However, in my experience, nine out of the twelve refugee Latin American patients, who have been unable to recover anything but an extremely marginal functioning in long-term follow-up, are males.

As time in the adoptive country passes, many refugee women find more opportunities than the ones they would have had prior to exile. Paid work, educational opportunities, birth control, health services, day care, and other social services may offer support to women's visions of more complete and fulfilling lives. With time and new experiences, women become increasingly aware of their potential for selfdevelopment and feel less threatened in exploring new opportunities, because they have little to lose and much to gain. As part of an overall process of self-development, women begin demanding greater participation from their male partners in housework and childrearing. They also demand greater personal space and freedom; realize that they are not the sexual property of their partners, and that they have the right to refuse their partners' sexual demands while learning to explore and enjoy their own sexuality. Once they learn that it is possible for them to achieve some financial freedom, upgrade academically, and gain recognized work skills, they become more aware of situations of oppression, abuse, and devaluation in the marriage and in society at large. Women realize that they can and should stop physical abuse of themselves and their children, situations to which they seem to be more susceptible during the initial resettlement period (Freire 1992; 1993a; 1993b).

In time, many women in abusive relationships experience a "turning point" or acquire a key insight-that the abusive situation will persist and that the only viable alternative is to leave the relationship (Pilowski 1993, 143). Women may end abusive relationships, though in contrast to previous decisions, their motives are based on personal well-being as well as that of their children. The realization that they have a choice about remaining in a dysfunctional marital situation or terminating it, without the stigma attached to separation and divorce in the country of origin, is described as very liberating.

Testimony: "My husband is attending college to become a draughtsman. He was studying to be an architect in our country. He pays the rent with the cheque we receive from the government and the rest of the money he spends on himself. He says that he needs the money to buy his lunch at school. He is ashamed of the lunches I prepare for him. He is also drinking a lot of beer. I manage to get second hand clothing for everybody and get the food at Kensington Market. There is a woman there who has a store and I go there with my daughter (while the other children are at 
school) to clean her house, do the laundry and cooking. I also help her around the store if necessary. She pays me a little money but gives me plenty of food. My husband doesn't help me with the grocery bags because he is ashamed of carrying bags. The few times I asked him, he took a taxi and I had to pay for it. He also used to push me around a lot until one day I called the police. He tells me that if I am going to behave like a Canadian woman he will leave me as soon as he finishes school. He might, but I have thought that he may be doing me and the children a favour by leaving. I left him once and I only came back because he begged me so much and I felt sorry for him. If I ever leave him again, I am not coming back."

The awareness of the option to leave an unsatisfactory relationship is reflected in another study that I am currently reviewing. The data collected seem to indicate that, most frequently, separations of exiled couples have been initiated by women. The range of new alternatives is reflected in the marital status 88 Latin American refugees who were my patients within a calendar year. Of the 29 males, 21 were married (7 were remarried), 4 separated, 3 single, and one widowed. Of the $59 \mathrm{fe}-$ males, 31 were married (10 were remarried), 10 separated, 13 single, 3 widowed, and 2 had missing husbands (Freire 1992). In the traditional societies of Latin America, this wide variety would be unusual.

\section{Latin American Men in Exile}

Latin American men have generally led more (emotionally) sheltered, more rewarding, more gratifying, and more self-centred lives than women in similar socioeconomic situations and life circumstances. This is a result of life in a society in which male status confers superior privileges and rights. Men's core identity is work-related, supported by a number of traditional socioculturally established roles as "authority figure," "provider," and "protector" within the family and community. Besides being considered the "head of the family," men are more often the ones who arrive in the new country with a professional, technical, or semi-technical degree, which is an additional asset in making them better candidates for ESL. or any other workrelated training. In exile, men experience all situations as more punitive, more depriving, more humiliating, and more degrading. For men with good verbal skills, high levels of education, and positions of political leadership and public life in the native country, life in the new country is devastating. Unable to provide financially for their families and feeling very inadequate in their parental and spousal roles, their sense of vulnerability is probably greater than that experienced by their wives. The new situation entails drastic losses in all the aspects that previously defined the identities of these men. Latin American men find themselves unable to work in their area of expertise, unable to communicate effectively in the new language at the level of public life to which they were accustomed, and without a political agenda that can be directly exercised, except through solidarity work. Through these experiences, the Latin American men's acute state of psychoemotional disorganization, brought about by the trauma and massive losses preceding resettlement, is further compounded by additional losses including drastic lowering of status experienced in the country of asylum.

These men encounter an enduring situation in which they cannot exercise a great deal of their previous self-development. Even under conditions in which they can apply certain skills or abilities, these do not reflect real gains or acquisition of new skills, but rather the recovery of something lost (e.g. a driver's license or a bank account). Most do not recover their previous employment credentials, though in time they may find work related to their field of expertise; physicians and engineers become technicians, architects become draughtsmen, and teachers become translators. Latin American refugee men with lower levels of education become factory workers, truck drivers, cleaners, or remain unemployed. Their core sense of mas- culinity and power is at risk, and they have tremendous difficulties in finding experiences that may counteract their losses and grief. Unlike women, they have been unable to retain a basic task or meaning in their lives throughout the ordeal; every aspect of their functioning and their identity has been disrupted. Equipped with a repertoire of coping mechanisms geared to function well under normal, predictable, and crisis-free circumstances, the men cope less well than the women in dealing with adverse conditions. In situations of crisis, the men generally tend to avoid, deny, or minimize reality. They may have difficulty verbalizing their emotions, particularly the negative ones, such as fear, anxiety, and anger. They become painfully aware of the severe losses in occupational status, effective parental role, their role as financial providers, and their use of the language of the receiving society. Their political projects, agendas, and sources of power are non-existent or meaningless in the new country.

When Latin American men realize that it will take longer than expected to recover their occupational status, invariably, they often redirect their energy into political and solidarity activities as a way of maintaining meaning in their lives, and in the hope of "going home" within a short time. Unfortunately, over a period involvement in political and solidarity activities within the community tends to decrease or disappear altogether (Freire 1989; 1993a). In a sample of 107 Latin American refugees, in which males were over-represented, 42 percent had suffered prolonged unemployment (longer than six months), 65 percent had suffered severe loss of occupational status, the number of factory workers had doubled at the expense of professionals, and active political participation had decreased from 70 to 35 percent (Freire and Berdichevsky 1984).

As time passes, men's initial expectations, hopes, and fantasies for rebuilding a life and a new self have to undergo substantial accommodations. Once again, the accommodations are 
rarely successful. In trying to assert a hurting, devalued self and a fragile sense of masculinity, men often resort to violence against themselves (suicide attempts); violence against others (wives and children) (Freire 1989; 1992; 1993; 1993a); increased alcoholic intake; and sexual promiscuity. They also seem to devalue the receiving society for longer periods than do the women. In contrast to women, they resist seeking professional services, they do not attempt to create or use existing support systems, and even reliance on friends tends to be minimal or non-existent.

Testimony: "I was the vice-president of a big company. I am sure that when I go back to my country I could recover my job. I don't need to learn English, I only would like to speak it to be able to let these people [Canadians] know of the political situations in our countries. These people don't know anything about politics. They don't have anything to teach us. I could offer a lot but I can't because I don't have the Canadian experience. I don't want to have Canadian experience. We have been waiting already 12 years, then it wouldn't take 1 or 2 more years now for a change in government. I really don't mind working as a school caretaker for the time being. My wife thinks I haven't tried hard enough to do something else, but I really don't mind. I really don't care any more."

More often than not, the dynamics that evolve in the marital dyad are conflictive and difficult to negotiate or non-negotiable. Men generally feel extremely threatened by women who, over time, become more independent and acquire interests and goals beyond providing for their partners and children. The development of new aspects of women's identity is even more disturbing to men in the context of their own increased vulnerability and "loss" of some of their rights, privileges, and territory which, pre-exile, were taken for granted. Strife ensues because most men are unable to accept a more complete woman beside them.

Women set increasing limits on meeting their husband's demands, while simultaneously making demands of their own. The changes within the marital dynamics are very difficult for men to comprehend because of their own sociocultural intrapsychic/emotional constructs. The possibility that women may leave them may be the ultimate and harshest threat to a man's fragile sense of new self and, in the experience of this author, has precipitated a number of suicidal crises and homicidal threats and actions from Latin American men (Freire 1992).

Testimony: "I don't understand why my wife gets so upset because I don't help around the house. It is true that we both work but men's work is always harder and heavier than women's work. Housework is women's work anyway. She doesn't like that I go out on weekends to play soccer and hang out with the guys. She wants me to take her and the children to the games. She never complained about any of these things before we came to Canada. Now she doesn't even want to sleep with me if we have a disagreement. I really don't get it and I get very angry. Since she has been working she has been getting all kinds of weird ideas about her rights to go out or having an affair if I do so. She forgets that what makes the difference is that $l$ am a man and she is a woman."

\section{References}

Acousta, S., and P. Fahm. 1989. " La Salud Mental y La Doble Represion de las Mujeres." Proceedings, 2nd International Conference on Health, Political Repression and Human Rights, November. 48. San Jose, Costa Rica: Centres, Institutions and Professionals Working for the Care of Victims of Organized Violence.

Agger, I. 1989a. "Couples in Exile." Proceedings, 2nd International Conference on Health, Political Repression and Human Rights, November. 71. San Jose, Costa Rica: Centres, Institutions and Professionals Working for the Care of Victims of Organized Violence.

. 1989b. "Sexual Trauma in Refugee Women." Proceedings, 2nd International Conference on Health, Political Repression and Human Rights, November, 73. San Jose, Costa Rica: Centres, Institutions and Professionals Working for the Care of Victims of Organized Violence.
1993. La Pieza Azul. Testimonio Femenino Del Exilio. Santiago, Chile: Ed. Cuarto Propio.

Brown, W., George and T. Harris. 1978. Social Origins of Depression: A Study of Psychiatric Disorder in Women. New York: Free Press.

Buzagalo, M., and G. Linblad. 1989. "Tratamiento en Grupo de Mujeres Latinoamericanas Que Han Sido Torturadas, Refugiadas en Suecia. Un Enfoque Cuerpo-Psique." Proceedings, 2nd International Conference on Health, Political Repression and Human Rights, November. 46. San Jose, Costa Rica: Centres, Institutions and Professionals Working for the Care of Victims of Organized Violence.

Carli, A. 1991. "Terapia Breve Con Mujeres Latinoamericanas en Crisis de Separacion." Paper presented at V Congreso Pluridisciplinario: Cultura y Situacion Psicosocial en America Latina, September. Hamburg University, Germany.

Chesler, P. 1972. Women and Madness. New York: Avon Books.

Dasberg, H. 1987, April. "Social Aspects of Trauma Following War, Genocide and Terror." Working Group Proceedings. Health Hazards of Organized Violence, 53-66. Rijswijk, Netherlands: Ministry of Welfare, Health and Cultural Affairs

Dunn, M., M. Oeur, and M. Reczycki. 1989. "Helping Tortured Cambodian Widows Journey Towards Health." Proceedings, 2nd International Conference on Health, Political Repression and Human Rights, November, 71. San Jose, Costa Rica: Centres, Institutions and Professionals Working for the Care of Victims of Organized Violence.

Fornazzari, X., and M. Freire. 1990. "Women as Victims of Torture." ACTA Psychiatry Scand, 82: 257-60.

Freire, M., and R. Berdichevski. 1984. "Economic and Political Exiles from Latin America." Paper presented at the Conference on Latin American Community Focus on Adjustment. September. Toronto: Hispanic Council.

Freire, M., and X. Fornazzari. 1989. "The Experiences of Refugee Women." Proceedings. 2nd International Conference of Individual Centres and Institutions Concerned With the Care of Victims of Organized Violence, November. "Health, Political and Human Rights." November. 74. San Jose, Costa Rica.

Freire, M. 1989a. "Latin American Refugees, Adjustment and Adaptation." Canadian Woman Studies, 10, 1.

- 1989b. "Refugee Children and Their Families." Paper published in the collec- 
tion of papers presented at the International Symposium on The Refugee Crisis: British and Canadian Responses, January. Toronto: Refugee Studies Program, York University, and Oxford: Oxford University.

-. 1990a. "Refugees, E.5. L. and Literacy: Trying to Reinvent the Self in a New Language." Refuge. York University, Toronto. 10, 4: 3-6.

-. 1990b. "Refugees: Trying to Reinvent the Self in a New Language." Paper delivered at the 3rd International Conference of Individual Centres and Institutions Concerned With the Care of Victims of Organized Violence, November. "Health, Political and Human Rights." 74. Santiago, Chile.

-.1991. "Immigrant and Refugee Children: Native Language as a Factor in the Development of the Self and the Competen Acquisition of a Second Language." Paper delivered at "Better Beginnings Better Future": Immigrant and Refugee Children's Mental Health Research Symposium, February. Toronto: Ministry of Community and Social Services.

1992. "La Mujer Latinoamericana. Perspectiva Sicosocial Del Exilio y Retor no." To be published as a collection of papers presented at the Primer Congresso Internacional, Salud Sicosocial, Cultura y Democracia en America Latina, November. Hamburg, Germany: Hamburg University, I.P.D. and Asuncion, Paraguay: Atyha.

-. 1993. "Mental Health, Culture and Youth" in R. Masi, L. Mensah and K. McLeod, eds. Health and Culture 22: 79119. New York: Mosaic Press.

------1993a. The Refuge Expl'riellce: A Reconstructive Modelfrom Psychodynamic Perspective. Unpublished manuscript.

-.1993b. "Violencein the Refugee Community." Paper delivered at the Human Rig/Its, Mental Health and Therapy in a Radically Changing World Conference. January. Banff, Alberta.

Frieze, I. et al. 1978. Womell and Sex Roles. New

York: W.W. Norton \& Co.

French, M. 1992. The War against Womell. To ronto: Summit Books.

Giller, J., and S. Kabagandas. 1989. "The Silent Suffering of War and Rape in a War-torn Country". Proceedings, 2nd International Conference of Individual Centres and Institutions Concerned With the Care of Victims of Organized Violence. November. "Health, Political and Human Rights." 74. San Jose, Costa Rica.

Gomez-Mango, E. 1985. "EI Migrante y Sus Signos." Revista De Psicoterapia Psycoanalitica, 4: 81-91. Audepp, Uruguay.
Moussa, H., E. Allmen, and K. Ptolemy. 1988. "Women Refugees: Cultural Adjustment as Empowerment." Paper delivered at International Consultation on Refugee Women. November. Canadian Council for Refugees. Geneva, Switzerland.

Pilowski, J. 1993. "Clinical Implications of the Practise of Sexual Torture on Women." Paper delivered at XIXth International Congress on Law and Mental Health. June. Lisbon, Portugal.

-. 1993a. The Price of a Wife is Thirteen Cents: An Exploration of Abused Spanishspeaking Women. Unpublished doctoral dissertation. Toronto: O.I.S.E., University of Toronto.

Reynell, J. 1989. Political Pawns. Oxford: Refugee Studies Programme, Oxford University.

Spencer-Nimmons, N., and C. Wong. 1989. "Refugee Women: Canadian Concerns, Canadian Considerations." Paper published in the collection of papers delivered at the International Symposium: The Refugee Crisis: British and Canadian Responses. Crisis: British and Canadian Responses.
Toronto: Refugee Studies Program, Toronto: Refugee Studies Program,
York University, and Oxford, England: York University, and Ox
Oxford University, January.

Tyhurst, L. 1951. Displacement and Migration: A Study in Social Psychiatry. American !oumal of Psychiatry, 107, 561-68.

Valenzuela, M.E. 1987. Todas Ibamos A Ser Reinas. Edicions Chile y AmericaCESOC, ACHIP. :J

\section{RECENT PUBLICATION}

\section{African Refugees: \\ Development Aid and \\ Repatriation}

Edited by

Howard Adelman and John Sorenson Published by Westview Press/York Lanes Press ISBN 155014-229-1 he, 264 pp, indexed. $\$ 39.90$

\section{Available from: York Lanes Press Suite 351, York Lanes York University North York ON M3] IP3 \\ Fax: (416) 736-5837}

Continued from page 19/ Women's Groups

In the Fall of 1993, Women in Black recorded the reactions of passersby to their weekly anti-war protests on Belgrade street (Zajovic, 1994). As they have noted (Zajovic, 15-16), men are generally more aggressive than women, especially in their gestures. They often approach women gestures. They often approach women
protesters in groups. Some of the recorded protesters in groups. Some of the recorded
reactions were: "Go to Alija Izetbegovic reactions were: "Go to Alija Izetbegovic
[President of Bosnia- Herzegovina]. No [President of Bosnia- Herzegovina]. No
one in Serbia wants war. You are converters to Islam;" "Are you the enemy representatives?;" "Go to Zagreb, to Tudjman" [President of Croatia];" "Go to the American or the German Embassy' Go to Vatican!

They are responsible for this. Ask Clinton and the Pope what they have done';" "You are wearing excellent clothes. Who pays you?;" "Do you remember the Ustasa concentration camp Jasenovac?" [concentration camp in Croatia where hundreds of thousands of Jews and Serbs were exterminated during the Second World War].

15. Unpublished work, distributed through the women's groups network in the former Yugoslavia.

\section{References}

Aleksov, Bojan. 1994. Deserters From the War in the Former Yugoslavia. Belgrade: Women in Black. Belic, Martina and Kesic, Vesna. (n.d.). Centre For Wometl War Victims - Report. Zagreb: Centre For Women War Victims.

Globus. 1992. Zagreb Weekly Magazine, December. Human Rights Worldwide, 1, (4). March, 1994. Korac, Maja. (In press)

"Understanding Eth

nic-National Identity and its Meaning: Questions from Women's Experience." In Womell's Studies Intemational Forum. New York, Oxford: Pergamon Press.

Milosavljevic, Milisav, ed. 1993. Refugee and Host Family Survey. Belgrade: UNHCR and Institute of Social Policy.

Posarac, A., S. Bogosavljevic and M. Kovacevic. 1994. "Poverty In Yugoslavia." Belgrade Economic Institute, International Federation of Red Cross and Red Crescent. Vreme, November 1994.

Vreme. 1993. Belgrade Weekly Magazine, January.

1994. Belgrade Weekly Magazine, November.

Zajovic, Stasa, ed. 1993. Women/or Pellce. Bel grade: Women in Black. 1994. Zcnc zllmir (Women for Peace) Belgrade: Zene u crnom (Women in Black). : J 


\section{CRS/ YORKLANES PRESS PUBLICATIONS}

\section{FORTHCOMING TITLES}

Asylum-A Moral Dilemma by Rabbi Gunther Plaut (co-publisbed with Greenwood Press)

Refugee Rights: Report of a Comparative Survey by James C. Hatbaway and Jobn A Dent

Cambodian Refugees in Ontario: An Evaluation of Resettlement and Adaptation by Janet McLellan

From Uprooting to Surviving: Resettlement of the Vietnamese-Chinese Boat People in Montréal, 1980-90

by Larry Lam

Boat People in Hong Kong: Transition to Nowhere by Larry Lam

Somali Refugees in Toronto: A Profile by Edward Opoku-Dapaab

Sri Lankan Refugees in India by Asba Hans

\section{RECENT PUBLICATIONS: BOOKS}

African Refugees: Development Aid and Repatriation, edited by Howard Adelman and John Sorenson (1994); $\$ 39.90$

Legitimate and Illegitimate Discrimination: New Issues in Migration, edited by Howard Adelman; $\$ 22.95$

Immigration and Refugee Policy: Australia and Canada Compared, edited by Howard Adelman, Lois Foster, Allan Borouski and Meyer Burstein (1994) (UofT Press and Melboume University Press)

Volume One: Context, Policy and Implementation \$24.95

Volume Two: Settlement and Impact $\$ 24,95$

Breaking Ground: The 1956 Hungarian Immigration to Canada, edited by Robert H. Keyserlingk (1993);\$12.95

Taking Refuge: Lao Buddhists in North America, Penny Van Esterik (1992); \$12:95

Refuge or Asylum: A Choice for Canada, edited by Howard Adelman and C. Michael Lanpbier (1991), \$18.95

Refugee Policy: Canada and the United States, edited by Howard Adelman (1991), \$20.95

Soviet-Jewish Emigration and Resettlement in the 1990s, edited by Tanja Basok and Robert J Brym (1991); $\$ 15.95$

The Indochinese Refugee Movement, edited by Howard Adelman (1980), $\$ 7.50$

\section{OCCASIONAL PAPERS AND REPORTS}

The Genesis of a Domestic Refugee Regime; The Case of Hungary, edited by Howard Adelman, Endre Sik and Géza Tessenyi (1994); $\$ 14.95$

So That Russia Be "Saved": Anti-Jewish Violence in Russia, Its Roots and Consequences, Tanya Basok and Alexander Benifand (1993); \$9:95

The Refugee Crisis in Russia, Rozalina Ryvkina, Rostislav Turouskiy and Robert Brym (1993); \$9.95

Adaptation of Ghanaian Refugees in Toronto, Edward Opoku-Dapaab (1993); $\$ 12.50$

Report on the Workshop for African Community Groups in Toronto, Edward Opoku-Dapaah (1992), \$12.50

Directory of African Community Groups in Toronto, Edward Opoku-Dapaab (1992)\$12.50

The International Refugee Crisis, edited by Howard Adelman (1990); $\$ 12.50$

Shipping: Please add $\$ 2.50$ for one item and $75 \mathrm{c}$ for each additional item. Canadian residents add $7 \%$ GST on the total amount. P.O. accepted. Send your order by fax or mail to:

York Lanes Press, Suite 351, York Lanes, York University

4700 Keele Street, North York ON M3J 1 P3 Canada

Tel.: (416) 736-5843 • Fax: (416) 736-5837

Internet: refuge@vm1.yorku.ca 


\section{Centre for Refugee Studies YORK UNIVERSITY}

\section{Research Fellowships and Awards, 1995-96}

\section{A. Kathleen Ptolemy Research Fellowship}

The annual Cdn. $\$ 15,000$ Kathleen Ptolemy Research Fellowship is awarded to permit a visiting scholar from a developing country to undertake research on refugees. Priority will be given to female scholars interested in the study of refugee women who are in need of protection, and who demonstrate commitment to refugee rights advocacy or service to the disfranchised

\section{B. Naomi Harder Refugee A ward}

The annual Cdn. $\$ 15,000$ Naomi Harder Refugee Award is given to a York graduate student undertaking research on refugees. The award may not be held in conjunction with an external scholarship or any other teaching or research assistance. Preference will be given to doctoral candidates.

\section{Visiting Research Scholars}

CRS invites applications from scholars who hold or who have held a fulltime academic appointment or an equivalent teaching and / or research position. A Visiting Research Scholar will have an established or emerging reputation as a scholar of refugee studies. $S /$ he will be expected to provide significant input to Centre's ongoing research and graduate education programme. The maximum stipend will be $\$ 1,875$ per month of residency, including expenses, to a maximum of one academic year (eight months), with no possibility of renewal.

\section{Post-Doctoral Researchers}

CRS invites the application of scholars who have completed a Ph.D. or equivalent degree in refugee studies or a closely related field. While at CRS, a Post-Doctoral Researcher will pursue a clearly defined program of research in an area which coincides with and will contribute to an aspect of Centre's ongoing research. The maximum stipend will be $\$ 1,250$ per month of residency, including expenses, for a maximum of one academic year (eight months), with the possibility of renewal for up to an additional eight months.

Applications must be received by April 12, 1995. Candidates should submit a curriculum vitae, a statement of intent, academic records, two letters of reference and a sample of research or publications to the Centre for Refugee Studies.

For further information, please contact:

Associate Director, Education

Centre for Refugee Studies

York Lanes, 3rd Floor, York University

4700 Keele Street

North York ON M3J 1P3

Canada

Tel.: (416) 736-5663 • Fax: (416) 736-58

Internet: refuge@vml.yorku.ca

Maid in the Market

Women's Paid Domestic Labour

\author{
Edited by Wenona Giles \\ and Sedf Arat-Koç \\ ISBN 1-896686-35-0 \\ $1994 ; 14.95,138 \mathrm{pp}$
}

This book demonstrates that even when done in "public" and for pay, the work of housekeeping and caregiving in industrial society is problematic. By focusing on three different kinds of paid "domestic work" commodified housework, service work performed in commercial settings and service work that is marketed and sold in familistic terms, the book explores how the work of reproduction is subordinated and devalued in the market place when it is done for a wage.

In addition to the issues of class and the labour process, the book also focuses on the gender and racial/ethnic dimensions of the industrial solution to the reproduction of labour power. Paid housework is usually performed by women, especially immigrant, refugee, and working class women. The book argues for a new feminist debate on domestic work that willaddress the relationship between gender, class and race/ethnic relations to arrive at an evaluation of alternatives for privatized housework.

Published by:

Fernwood Books

P. O. Box 9409 , Station A

Halifax NS B3K $5 \mathrm{S3}$

Tel: (902) 422-3302

Fax. (902) $422-3179$

(C) Marlind Freire, 1995. This open-access work is licensed under a Creative Commons Attribution-NonCommercial 4.0 International License, which permits use, reproduction and distribution in any medium for non-commercial purposes, provided the original author(s) are credited and the original publication in Refuge: Canada's Journal on Refugees is cited 
Refuge York Lanes Press Centre for Refugee Studies Suite 351, York Lanes York University 4700 Keele Street, North York Ontario, Canada M3J 1P3 Phone: (416) 736-5843

Fax: (416) 736-5837 Internet: refuge@vm1.yorku.ca

\section{DIRECTOR, CENTRE FOR REFUGEE STUDIES}

Applications are invited for the position of Director of the Centre for Refugee Studies for an initial term of no fewer than three years and no more than five years, beginning on or before 1 July 1996. Established as an official University-based research unit in 1988, the Centre was named as a CIDA Centre of Excellence in 1991. The Director reports to the Associate Vice-President (Research).

The Director is responsible, in collaboration with others, for the research programme, education programme, finance and administration of the Centre. The Director is expected to fulfil the CIDA Centre of Excellence mandate, to provide leadership in the further development of the Centre, and to develop additional funding sources. The Centre is expected to operate on a cost-recovery basis; experience in budget management and in negotiation of research contracts would be an asset.
The Director would also be appointed to a department in the Faculty of Arts at York University and must have a distinguished record of scholarship, strong research interests in refugee studies and be a good teacher. The rank of the appointment is open and, if appropriate, could carry tenure at the outset. This appointment is subject to budgetary approval by the University. Preference will be given to applicants who would be appointed to the Philosophy or Political Science or Sociology Departments, but other departments will be considered.

York University is implementing a policy of employment equity, including affirmative action for women faculty.

In accordance with Canadian immigration requirements, this advertisement is directed to Canadian citizens and permanent residents.

Applications (including Curriculum Vitae and suggested references) should be sent by 3 April, 1995 to:

\section{Secretary of the Search Committee (CRS) \\ Office of the Dean, Faculty of Arts \\ S930 Ross Building, York University 4700 Keele Street, North York, Ontario Canada M3J 1P3}

For further information, please contact the Secretary of the Search Committee at telephone (416) 736-5260, or fax (416) 736-5641.

(4)

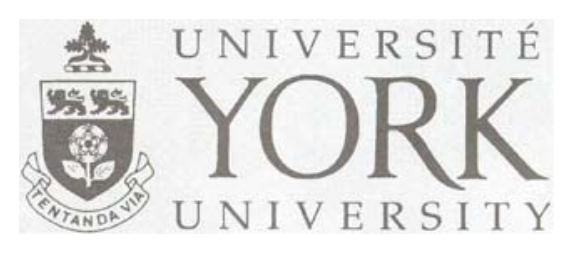

U N I V ER S I T Y 